S. Afr. J. Agric. Ext.,

Vol. 45, No. 1, 2017: $118-130$

Ekepu, Tirivanhu

DOI: http://dx.doi.org/10.17159/2413-3221/2017/v45n1a444

\& Nampala.

(Copyright)

\title{
ASSESSING FARMER INVOLVEMENT IN COLLECTIVE ACTION FOR ENHANCING THE SORGHUM VALUE CHAIN IN SOROTI, UGANDA
}

\author{
Ekepu, D., ${ }^{34}$ Tirivanhu, P. ${ }^{35} \&$ Nampala, P. ${ }^{36}$ \\ Correspondence author: D. Ekepu. Email: dekepu@gmail.com
}

\begin{abstract}
Farmer associations have been widely promoted in Uganda to bridge institutional gaps among smallholder farmers, however, their role in the sorghum (Sorghum bicolor) value chain and factors influencing membership to these associations have not been well documented. This study was conducted to assess the role of these farmer associations and socio-economic factors influencing membership. A survey questionnaire was administered to a randomly selected sample of 120 sorghum farmers in six sub-counties of Soroti, Uganda, where associations are established. A binomial logit regression model was employed to ascertain socio-economic factors that influenced membership to farmer associations. Results showed that $65 \%$ of respondents belonged to a farmer association. Regarding benefits of farmer associations, 55.8\% of the respondents received training in sorghum agronomy, $39.2 \%$ were trained on postharvest management, $35 \%$ engaged in collective marketing, $43.3 \%$ received credit and $3.3 \%$ processed sorghum as part of value addition for increased income. Gender and extension contacts significantly $(P<0.05)$ influenced membership to farmer associations. Even with adequate resources (human and financial), the most critical factors in the process of building functional farmer associations is gender and extension contacts.
\end{abstract}

Keywords: Collective action, farmer associations, sorghum, value chain, socio-economic factors, extension

\section{INTRODUCTION}

The population of sub-Saharan Africa is expected to reach 1.5 billion people by 2050 . These projections call for innovative food production systems in order to feed the growing population. There is need to increase the productivity of smallholder farmers who form the majority of farmers in the agricultural sector of most sub-Saharan African countries. Unfortunately, smallholder farmers continue to face challenges of high transaction costs and weak bargaining power. To offset these bottlenecks, smallholder farmers need to unite, have a collective voice and increase their bargaining power through the formation of farmer organisations (Pertev, 2014:27; Rwelamira, 2015:3).

The implementation of liberalisation and privatisation policies by most African governments over the last 25 years led to the collapse of many government-led cooperative societies that facilitated engagement in export markets. However, the demand for produce by companies in the local market is on the rise due to urbanisation and rising household incomes in Eastern

\footnotetext{
${ }^{34}$ Masters Candidate, Centre for Sustainable Agriculture, Rural Development and Extension, University of the Free State, Bloemfontein 9300, South Africa. Email: dekepu@gmail.com

${ }^{35}$ Post-Doctoral Research Fellow, Centre for Sustainable Agriculture, Rural Development and Extension, University of Free State, Bloemfontein, 9300, South Africa. Email: ptirivanhu@gmail.com

${ }^{36}$ Grants Manager, Regional Universities Forum for Capacity Building in Agriculture (RUFORUM), Uganda.

Email: p.nampala@ruforum.org
} 

Schiavone, 2005:6). According to Kaganzi et al. (2009:23), farmer collective action presents an opportunity for smallholder farmers to fulfil essential market prerequisites of quality, quantity and prompt delivery of produce to the consumers. Collective action occurs when farmers come together voluntarily to address common challenges (Shiferaw, Obare \& Muricho, 2006:1). The government of Uganda, through the National Agricultural Advisory Services (NAADS) program, invested considerable resources in establishing farmer groups to enhance market access for smallholder farmers (Kaganzi et al., 2009:23). It is however imperative to look beyond the market-access when advocating for collective action for smallholder farmers and study its importance on the entire value chain.

Previously, much attention on collective action had been paid to high value crops such as potatoes, fruits and vegetables (Kaganzi et al., 2009:23; Narrod, Roy, Okello, Avendaño, Rich \& Thorat, 2009:8). There is growing realisation on the importance of collective action in enhancing the value chain of traditional food crops (Mulu-Mutuku, Odero-Wanga, AliOlubandwa, Maling'a \& Nyakeyo, 2013:48). These crops include sorghum which is a major food and cash crop for many smallholder farmers in Soroti district, Eastern Uganda. At continental level, sorghum is the second most important crop in Africa, but the productivity of the crop is falling and one of the biggest reasons cited for this decline is weakness in institutions that serve the farmers (Macauley \& Ramadjita, 2015:3). Particularly in the Soroti district of Uganda, political instability and government liberalisation polices of the early 1990s led to the collapse of many formidable farmer organisations. Attempts to revive these farmer institutions has taken longer than anticipated.

The benefits of farmer groups are well documented (Shiferaw, Obare, \& Muricho, 2006:5; Adong, Okoboi \& Mwaura, 2012:5; Fisher \& Qaim, 2012:1255). However, these farmer groups in most rural communities in Uganda remain small, informal and weak to offer substantial assistance to smallholder farmers. It is against this background that Community Integrated Development Initiatives (CIDI), a local NGO in Soroti initiated the establishment of farmer associations in the district to offer a collective voice and bargaining power to these smallholder farmers. Farmer associations are formed when farmer groups merge to form one bigger organisation. The establishment of farmer associations was implemented under the Soroti Integrated Development Project (SIDP III). This project was aimed at improving social wellbeing through enhanced household incomes and food security hinged on sustainable agriculture policies and solutions. The associations were established in the 5 subcounties of Asuret, Arapai, Gweri, Katine and Tubur (CIDI, 2013:42).

Fischer \& Qaim (2012:1255) stress the need to recognise the underlying conditions that can enhance farmer involvement in collective action. Some studies have been conducted to assess determinants of membership to farmer groups (La Ferrara, 2002:235; Adong et al., 2012:1; Fischer \& Qaim, 2012:1261), but there is limited research in Uganda regarding the role of farmer associations in the sorghum value chain and the factors that influence membership to these farmer associations. This study addresses this research gap. Therefore, the aim of this study is to examine the role of farmer associations as a collective means to enhancing the sorghum value chain in Soroti district, Eastern Uganda. Socio-economic factors influencing membership to farmer associations were also assessed and discussed.

\section{CONCEPTUAL FRAMEWORK}


Farmer organisations remain fundamental to the wellbeing of smallholder farmers because they lower transaction costs of accessing input and output markets, adopting new technologies and obtaining agricultural information (Stockbridge, Dorward \& Kydd, 2003:2). The theory of collective action through organised groups came to the spotlight in 1965 by Macur Olson in the publication entitled, 'The logic of collective action: public goods and the theory of groups'. According to Olson, farmer organisations serve the interests of their members to advance economic benefits to all members in the group (Olson, 2009:7). In this study farmer organisations are categorised into co-operatives, farmer associations and farmer groups. Less focus was paid to commodity co-operatives since most of them collapsed during the early 1990s. Although these farmer organisations increase farmers' bargaining power, membership depends on several underlying conditions (Fischer \& Qaim, 2012:1255). For this study, several socio-economic attributes were assessed to determine their influence on membership to farmer associations.

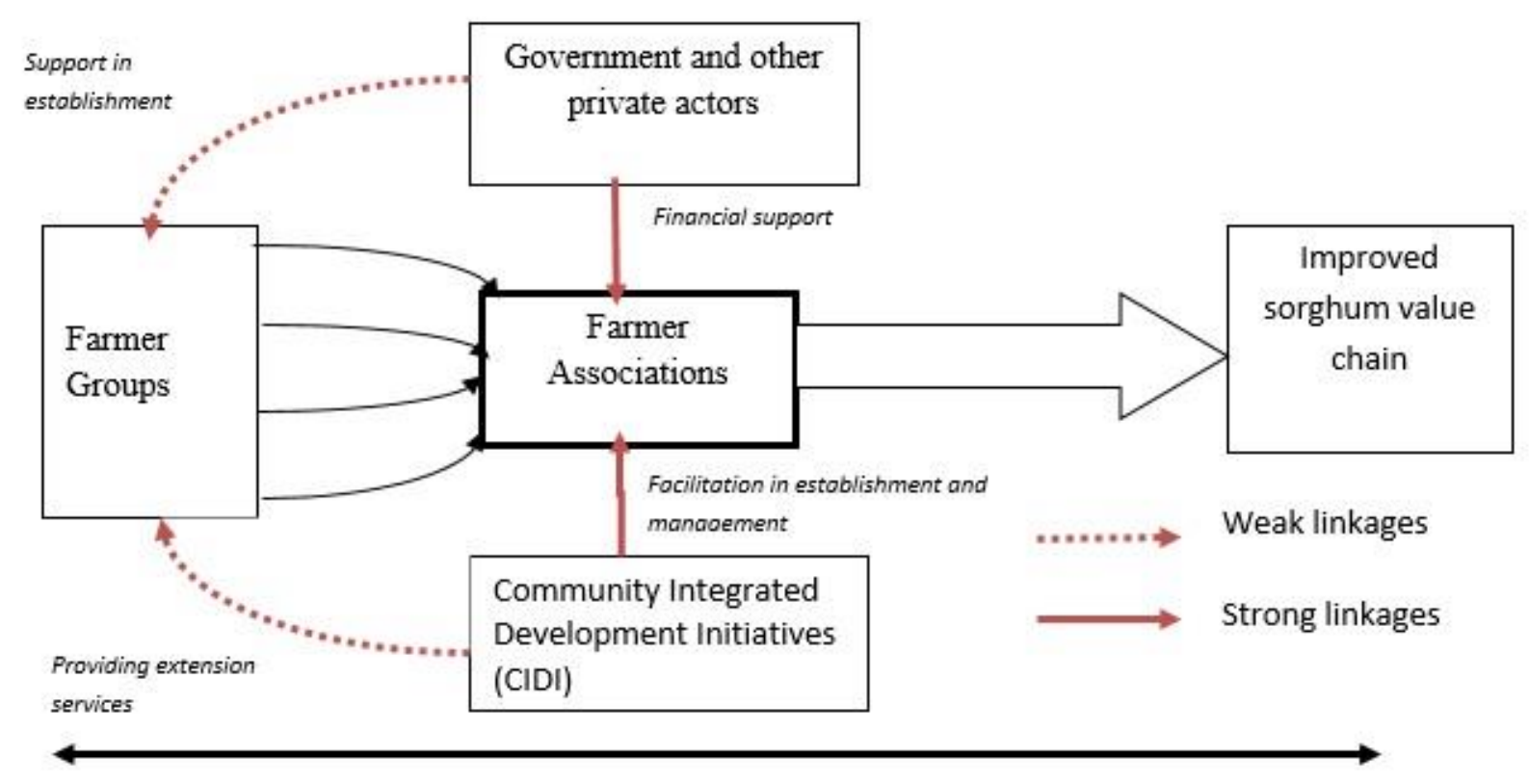

Underlying socio-economic factors influencing membership to farmer organizations

Figure 1: A conceptual framework for the study on farmer involvement in collective action for enhancing the sorghum value chain.

As indicated in figure 1, membership to a farmer group is mandatory if a farmer is to join a farmer association. The farmer groups were mostly established with support from the government of Uganda under the NAADS program. However, CIDI, a local NGO in Soroti initiated the formation of farmer associations to secure collective action of smallholder farmers and increase their bargaining power. Nonetheless, not all farmers belonging to farmer groups have joined these producer associations. Therefore, this study investigated socioeconomic factors such as age, household size, gender, credit, education, farm size, extension contacts and off-farm income as determinants of membership to farmer associations.

\section{THE SORGHUM VALUE CHAIN OF SOROTI, UGANDA}

Sorghum is a very important crop in Soroti, and Uganda as a whole. The crop is predominantly grown in northern and Eastern Uganda for consumption. However, entrance of 


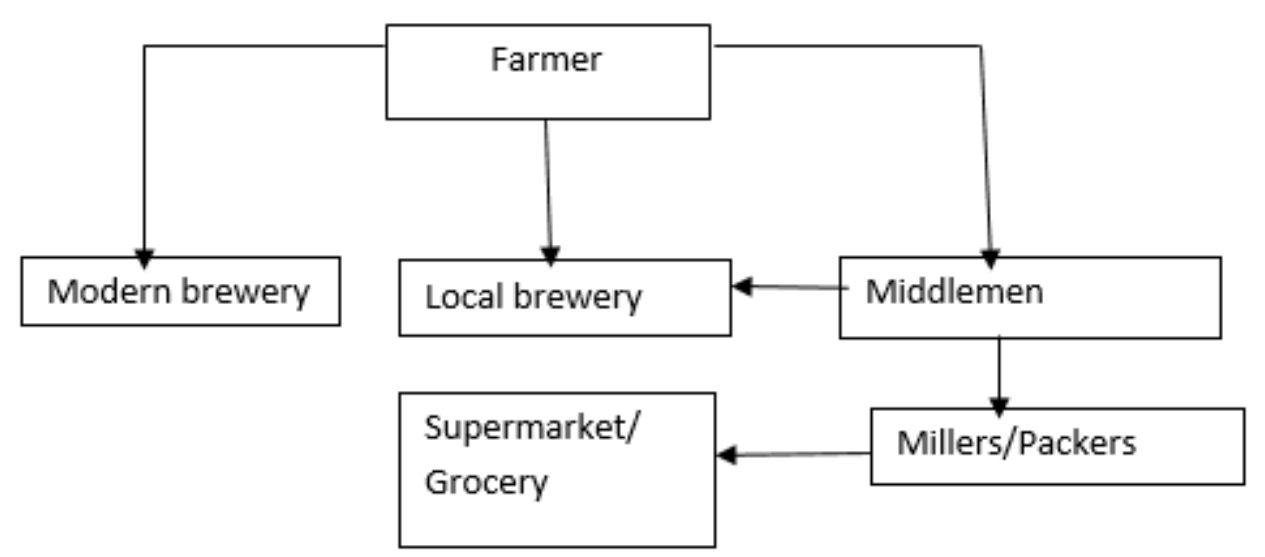

Figure 2: The sorghum value chain in Soroti, Uganda (Adapted from USAID, 2010:54).

Sorghum sold to modern breweries such as Nile Breweries is used to make commercial beer notably; Eagle extra and Eagle lager (figure 2). However, the local breweries buy sorghum from farmers to make local sorghum brew called Malwa or Ajon in Luganda and Ateso respectively. The middlemen also buy sorghum from farmers and sell it to millers where it is packed and supplied to supermarkets. In addition, the middlemen sell the sorghum to the local brewery in Soroti district.

\section{CATEGORIES OF FARMER ORGANISATIONS THAT FACILITATE COLLECTIVE ACTION 4.1 Co-operatives}

The significance of collective action to smallholder farmers through cooperatives has shown mixed results over the years (Narrod et al., 2009:9; Fischer \& Qaim, 2012:1255). For instance, cooperatives reduced the marketing cost of grapes in India (Roy \& Thorat, 2008:1), positively impacted on the dairy sector in Ethiopia (Holloway, Nicholson, Delgado, Staal \& Ehui, 2000:287) and facilitated high prices for coffee producers in Costa Rica (Wollni \& Zeller, 2007:2). Cases where co-operatives have failed farmers have also been reported in literature (Ortmann \& King, 2007:45; Bond, Carter \& Sexton, 2009:71). In Uganda, many cooperatives that existed before the early 1990s are out of operation, mainly due to policy dissatisfaction (Kwapong \& Korugyendo, 2010:2; Ampaire, Machethe \& Birachi, 2013:1). These cooperatives were mostly oriented to marketing cash crop commodities like coffee, cotton and cocoa. Less attention was given to traditional food crops. The specific policy environment issues that have led to the collapse of cooperatives in Uganda include: market liberalisation, insecurity and political turmoil as well as poor management (Kwapong \& Korugyendo, 2010:1). Some reforms are being implemented to try and revive co-operatives in Uganda to deal with challenges facing rural farming communities. Through their umbrella organisation, the Uganda Co-operative Alliance (UCA), the co-operatives now provide an array of services including among others: access to credit through Savings and Credit Cooperative Organisations (SACCOs), collective marketing of produce sold in bulk through the Area Co-operative Enterprises (ACEs) and, Rural Producer Organisations (RPOs) at the grassroots (Kwapong \& Korugyendo, 2010:1). 


\subsection{Producer associations}

Producer associations are formed when many farmer groups merge to form a bigger association. A producer association enhances collective bargaining power and gives a bigger voice to farmers. The government of Uganda is therefore, promoting the establishment of several farmer associations in the country to help bridge the marketing gap faced by smallholder after the collapse of many co-operative societies in the early 1990s (Ampaire, Magala \& Lwasa, 2013: 964). In South Africa, the formation of smallholder marketing associations to overcome barriers to smallholder market access has been emphasised by Magingxa \& Kamara, (2003:6). Associations have also been reported to facilitate extension service delivery, provision and delivery of inputs to their members (Wang, 1979:161; Baah, 2008:395). In the Soroti district of Eastern Uganda, farmer associations have been established as an integrated approach to improving social wellbeing through enhanced food security and household incomes when farmers participate in collective action (CIDI, 2013:42). Studies on the factors influencing membership to farmer associations in Uganda are almost non-existent. Therefore, to add knowledge to this discourse, socio-economic factors influencing membership to farmer associations in Soroti, Uganda were assessed in this study. Also when studying the environment under which farmer associations operate, the immediate environment which encompasses membership, output and assets have been reported to offer a bigger influence to the functioning of farmer associations (Poole \& de Freece, 2010:61).

\subsection{Farmer groups}

Farmer groups are the smallest units of farmer organisations. They currently represent the main strategy adopted for transforming the agricultural sector in Uganda because they are regarded as important ingredients for enhancing market access, obtaining credit information for their members and fostering technology adoption (Adong et al., 2012:1). Even the implementation strategy for the National Agricultural Advisory Services (NAADS) is hinged on the concept of farmer groups. However, most of these farmer organisations remain informal, lack sufficient organisation in their membership structures and still experience high transaction costs in the crop value chain. A justification for the use of a farmer group approach in agriculture has previously been laid down by several authors; for example, Mbowa, Shinyekwa \& Mayanja Lwanga (2012:11) reported that farmer groups led to improved value addition in the milk value chain in Uganda. Farmer groups also increase economies of scale (Loevinsohn, Mugarura \& Nkusi, 1994: 141), improve access to markets (Aliguma, Magala \& Lwasa, 2007:4) as well as aid access to new agricultural technologies (Gibson, Byamukama, Mpembe, Kayongo \& Mwanga, 2008:217). Despite these benefits, the farmer groups in Uganda are small in size so they continue facing challenges of high transaction costs due to low economies of scale and cannot provide substantial bargaining power to their members. Furthermore, there is need for farmer groups to merge together and form farmer associations that can generate a more collective power and influence.

Literature on factors influencing membership to farmer associations remains scarce. However, for producer organisations like farmer groups, some information on attributes including gender, age, education, farm size, participation in off-farm activities and household size have been reported to influence participation in groups (Towo, 2004:9; Sabates-Wheeler, 2006:3; Davis, Nkonya, Kato, Mekonnen, Odendo, Miiro \& Nkuba, 2010:9; Adong et al., 2012:1). There is however, paucity of information on factors influencing membership to farmer associations in Uganda. Socio-economic factors assessed in this study are; gender, age, family size, farm size, education, credit, extension contacts and off-farm income. 
S. Afr. J. Agric. Ext.,

Vol. 45, No. 1, 2017: $118-130$

DOI: http://dx.doi.org/10.17159/2413-3221/2017/v45n1a444
Ekepu, Tirivanhu

\& Nampala.

(Copyright)

\section{RESEARCH METHODOLOGY 5.1 Study site}

The study was conducted in Soroti district located in Eastern Uganda. Soroti is bordered by 4 districts; Serere in the South, Amuria in the North, Kaberamaido in the west and Ngora in the East. It is one of the dominant sorghum producing regions in Uganda. According to a Uganda survey on agriculture 2008/2009; Soroti district was ranked the number one producer of sorghum in the country (UBOS, 2010:15). However, statistics showed an overall decline in sorghum yields in Uganda for the period 2007 to 2014 (Factfish, 2015). The smallholder farmers in the district have been engaged in the production of sorghum on a contract basis ever since the Eagle Lager project was launched by Nile Breweries Ltd in 2002. Besides growing sorghum for sale, the crop is also widely grown for home consumption. This can partly be attributed to weak institutions, which is a major challenge, that can otherwise support farmers and empower them to overcome production constraints along the sorghum value chain in Soroti.

\subsection{Research design and sampling technique}

A cross-sectional survey design was employed in this study. A multi-stage random sampling approach was used to select respondents who participated in the survey. A list of 120 sorghum farmers was selected from 6 sub-counties of Soroti district; Kamuda, Tubur, Katine, Asuret, Gweri and Arapai. These sub-counties were chosen because CIDI has established several farmer associations in those areas (CIDI, 2013:42) and much of the sorghum in Soroti district is produced in these outlying sub-counties. A total of 20 respondents were randomly chosen from each of these sub-counties, the respondents were then traced to their parishes and villages.

\subsection{Data collection and analysis}

Face-to-face interviews were conducted to collect quantitative data using a semi-structured questionnaire. Open-ended questions were also included in the survey questionnaire to capture farmers own views. The questionnaire was pre-tested and enumerators were trained on how to administer the survey instrument. The data from the questionnaires were cleaned, coded and analysed using SPSS version 21. Descriptive statistics were used to summarise the study findings. A binomial logit model was used to ascertain socio-economic variables that influenced membership to farmer associations, since the decision to join a farmer association is dichotomous.

\subsection{Specification of the model}

This study adopted a binomial logit regression model by Agresti \& Barbara (2009) and Peng $\&$ So (2002:33) that shows the relationship between the dependent and the independent variables as:

$$
\operatorname{Ln}(P i / 1-P i)=\log (\text { odds })=>\log Y=\alpha+\beta x
$$

The probability of occurrence of the dependent outcome (decision to join a farmer organisation) can be predicted using the following equation which is derived from the above equation (1). An antilog of both sides of the equation gives: 
S. Afr. J. Agric. Ext.,

Vol. 45, No. 1, 2017: $118-130$

DOI: http://dx.doi.org/10.17159/2413-3221/2017/v45n1a444

$\operatorname{Pi}=\operatorname{Pi}(Y)=\frac{e^{\alpha+\beta \mathrm{x}}}{1+e^{\alpha}+\beta \mathrm{x}}$

Taking the natural log of Equation (2) gives the following logit model:

$\operatorname{Ln}[\mathrm{Pi} /(1-\mathrm{Pi})]=\beta 0+\beta 1 X 1 i+\beta 2 X 2 i+\ldots \ldots \ldots+\beta k X k i$

Where $Y$ is the dependent variable, the subscript $i$ refers to the $i^{\text {th }}$ observation in the sample. $\mathrm{P}$ is the probability that a farmer joins a farmer organisation and $(1-P)$ is the probability that a farmer does not join a farmer organisation. ' $e$ ' is the base of the system of the natural logarithms. $\beta 0$ is the intercept term and $\beta 1, \beta 2, \ldots \ldots \ldots, \beta k$ are the coefficients of the independent variables $X 1, X 2, \ldots \ldots \ldots ., X k$ (age, farm size, education, household size, extension contacts, off-farm income, credit and farm size).

Table 1: Description of dependent and independent variables used in the logit regression analysis

\begin{tabular}{|c|c|c|c|}
\hline Observations & Variable description & $\begin{array}{c}\text { Variable } \\
\text { type }\end{array}$ & $\begin{array}{c}\begin{array}{c}\text { Hypothesised } \\
\text { sign }\end{array} \\
\end{array}$ \\
\hline \multicolumn{4}{|l|}{ Dependent variable } \\
\hline $\begin{array}{l}\text { Membership to a } \\
\text { farmer association }\end{array}$ & $\begin{array}{l}\text { Whether farmers belong to a farmer } \\
\text { association or not }\end{array}$ & Binary & N/A \\
\hline \multicolumn{4}{|l|}{$\begin{array}{l}\text { Independent } \\
\text { variables }\end{array}$} \\
\hline Age & $\begin{array}{l}\text { Number of years the respondent has } \\
\text { lived }\end{array}$ & continuous & - \\
\hline Household size & $\begin{array}{l}\text { Total number of people in the } \\
\text { respondent's household }\end{array}$ & continuous & + \\
\hline Farm size & Size of the farm in acres & continuous & + \\
\hline Education & $\begin{array}{l}\text { Number of years the respondent spent } \\
\text { in formal education }\end{array}$ & continuous & + \\
\hline Credit & $\begin{array}{l}\text { Whether the farmer borrowed money } \\
\text { in } 2015 \text { or not }\end{array}$ & categorical & + \\
\hline Gender & $\begin{array}{l}\text { Whether the respondent is male or } \\
\text { female }\end{array}$ & categorical & + \\
\hline Extension contacts & $\begin{array}{l}\text { Number of contacts with extension } \\
\text { staff in } 2015\end{array}$ & continuous & + \\
\hline Off-farm income & $\begin{array}{l}\text { Whether the respondent has a side } \\
\text { business to earn extra income or not }\end{array}$ & Categorical & + \\
\hline
\end{tabular}

\section{RESULTS AND DISCUSSION}

\subsection{Results}

6.1.1 Socio-economic characteristics and benefits of farmer associations to smallholder sorghum farmers in Soroti, Uganda

From data analysis, $55 \%$ of the respondents were female and $45 \%$ male. Furthermore, $73 \%$ of the respondents were married, $2.5 \%$ were single, $5 \%$ had divorced, $15 \%$ were widowed and $3.3 \%$ lived separate from each other. The households in Soroti had an average of 8 family 

of a farmer association.

Regarding the benefits of farmer associations to the sorghum value chain, $55.8 \%$ of the sorghum farmers who belong to an association indicated that they had received training in sorghum agronomy but only $39.2 \%$ were trained on postharvest management. Only $35 \%$ of the farmers were engaged in collective marketing in a farmer association. Credit from a farmer association was reportedly obtained by $43.3 \%$ of the sorghum farmers, and $3.3 \%$ carried out processing of sorghum into flour at the grain mill operated by the farmer association.

\subsubsection{Regression analysis}

The results from the regression analysis are shown in Table 2. Gender had a negatively significant $(\mathrm{P}<0.05)$ effect on membership to farmer associations whereas extension contacts had a positively significant $(\mathrm{P}<0.05)$ influence on membership to farmer associations in Soroti, Uganda. Although other variables like age of the respondent, education, household size, farm size, off-farm income, and credit were hypothesised to influence membership to farmer associations, they in fact had no significant effect on membership to farmer associations. The logit regression model correctly predicted $74.2 \%$ of the cases and explained 22.8\% (Cox and Snell R Square) and 31.4\% (Nagelkerke R Square) of the variance in smallholder farmer membership to farmer associations.

Table 2: Logit regression estimates of the socio-economic determinants of membership to farmer associations in Soroti, Uganda

\begin{tabular}{|l|l|l|l|}
\hline Variables & Coefficients & S.E & Sig \\
\hline Age of the respondent & 0.020 & 0.019 & 0.292 \\
\hline Gender & -1.203 & 0.539 & $0.026^{*}$ \\
\hline Education & 0.059 & 0.077 & 0.445 \\
\hline Household size & 0.067 & 0.062 & 0.278 \\
\hline Farm size & 0.089 & 0.111 & 0.422 \\
\hline Off-farm income & -0.727 & 0.477 & 0.127 \\
\hline Extension contacts & 0.428 & 0.129 & $0.001^{*}$ \\
\hline Credit & 0.672 & 0.470 & 0.153 \\
\hline Constant & -1.700 & 1.057 & 0.108 \\
\hline
\end{tabular}

-2loglikelihood 124.362

Cox and Snell R Square

0.228

Nagelkerke R Square

0.314

$\%$ correct predicted

$74.2 \%$

* Significant

Sig $=5 \%$ level of significance; S.E means standard error

\subsection{Discussion of findings}

Based on literature (Adong et al, 2012:5), the factors studied (age of respondent, gender, education, household size, farm size, off-farm income, extension contacts and credit) as variables hypothesised to influence membership to farmer associations. These factors are considered key in agricultural value chains. It is however, surprising that only gender and extension contacts significantly influenced participation and membership to farmer 
associations. Farmer organisations are formal structures in the agricultural production continuum and it would be expected that factors such as education, credit and income would influence membership.

The significance of farmer collective action in enhancing value chains in agriculture has been highlighted in literature (Hellin, Lundy \& Meijer, 2009:5; Adong et al., 2012:5). After the collapse of many co-operative societies in Uganda in the early 1990s, there is general consensus that any attempts to promote the establishment of farmer organisations should avoid mistakes of the past and address core issues facing smallholder farmers. Findings from this study show that farmer associations in Soroti provide a range of services to their members beyond just strengthening market access. These services range from extension service delivery to processing of produce. Similar findings were noted by Baah (2008:395) and Wang (1979:161) who reported farmer associations as organisations carrying out numerous roles beyond just strengthening market access.

Farmers get discouraged to join farmer organisations because of various reasons. High membership costs and reluctance by farmers due to lack of trust in collective action are some of the constraints to farmer participation in collective action cited in literature (Doeward \& Kydd, 2003:2; Hellin et al., 2009:6; Stockbridge). According to the views of some farmers in Soroti, their failure to join farmer associations in addition to high membership costs are, lack of awareness of the benefits of farmer associations, connectedness and favouritism of members. Connectedness and favouritism is related to local politics in Soroti. For instance, if the majority of the leadership of the farmer associations subscribe to a certain affiliation, they may block an individual farmer from joining the farmer association if he or she is from a different affiliation. Therefore, eliminating individual inclinations and considerations when mobilising farmers for development, is necessary for enhancing agricultural production (Egeru \& Majaliwa, 2016:716).

According to Adong et al., (2012:3) age and farm size were expected to influence membership to farmer associations. However, this was not found to be true in this study. This could be attributed to the fact that membership is open to any age group and that the decision to join is voluntary, not based on acreage of the farmer. The credit variable always increases the availability of capital that a farmer can use to subscribe to farmer organisations (Fischer \& Qaim, 2012:1261), but in this study it had no significant impact on membership to farmer associations in Soroti district. This could be explained by the fact that credit access to farmers in Soroti is still low and could not be a significant determinant to membership to farmer associations. A report by Bank of Uganda (BOU) also noted access to credit for farmers in Uganda as whole to be low because most lending institutions still perceive agriculture to be a very risky sector (BOU, 2016:58). Furthermore, off-farm income and education also had no significant effect on membership to farmer associations in Soroti, Uganda. This can be explained by most farmers practicing farming as their only vocation and the fact that the farmers in the rural part of Soroti are generally less educated respectively. Davis et al., (2010:11) found that less educated farmers tend not to join farmer associations. In addition, again differing from other studies done by Davis et al., (2010:11) and Adong et al., (2010:33), household size had no significant effect on membership to farmer associations in Soroti, Uganda. The reason could be that dependency ratios of families in Soroti do not hinder membership to farmer associations and any family member of the household can voluntarily join an association.

There was a positively significant $(\mathrm{P}<0.05)$ effect of extension contacts on membership to farmer associations in Soroti district. The reason could be that farmers who attend more 

associations. However, similar studies on factors influencing membership to farmer organisations have reported contrasting results. For example, Adong et al. (2012:23) found a negative relationship between access to extension workers and membership to farmer groups in Uganda. On the other hand, aligning with this study, Tolno, Kobayashi, Ichizen, esham \& Balde (2015:133) reported access to extension service to have a positively significant effect on membership to farmer groups in Guinea.

Gender negatively significantly $(\mathrm{P}<0.05)$ influenced farmers' decisions to join farmer associations in Soroti Uganda. A higher percentage of women participating in group activities has been reported in Uganda (Adong et al., 2012:22) and this could be a reason why the gender variable is a significant determinant to membership to farmer associations in Soroti, Uganda. Although males always influence the making of household decisions, Tolno et al., (2015:133) found less participation of males in group activities in Guinea. However, Towo (2004:10) noted that women may sometimes be faced with domestic chores which can affect their participation in groups. It is therefore, recommended that strengthening the implementation of pro-gender policies will go a long way in enhancing strong women participation in group activities (Towo, 2004:8).

\section{CONCLUSION AND RECOMMENDATIONS}

Farmer associations in Uganda have become an important form of collective action for smallholder sorghum farmers in Soroti. The factors that significantly influenced membership to farmer associations in this study were gender and extension contacts. Therefore, when promoting the establishment of farmer associations, the stakeholders should be gender sensitive to enhance participation of both men and women. This will strengthen good values of compassion, caring as well as sustainability of these rural producer organisations. Gender in this respect goes beyond increased number of women and youth but also implies inclusivity approaches that ensure that the design, implementation and uptake of innovations and processes (such as farmer associations) are based on gender sensitive tools. Given the low coverage of extension service delivery in Uganda, more efforts should be put towards improving access to extension services in Uganda by the private actors and government agencies with the mandate for delivering agricultural extension services. Therefore, there is a need for innovative extension approaches that promote more frequent engagement between end-users and extension agents.

\section{ACKNOWLEDGEMENT}

The authors acknowledge financial support from Intra-ACP CSAA mobility project and RUFORUM's Field Attachment Programme Awards (FAPA) for conducting this study.

\section{REFERENCES}

ADONG, A., OKOBOI, G. \& MWAURA, F. 2012. What determines membership to farmer groups in Uganda: Evidence from the Uganda Census of Agriculture 2008/2009.

AGRESTI, A. \& BARBARA, F. 2009. Statistical methods for the Social Sciences. 4th ed. Upper Saddle River, NJ: Pearson Hall Inc.

ALIGUMA, L., MAGALA, D. \& LWASA, S. 2007. Uganda: Connecting small-scale producers to markets: The case of the Nyabyumba United Farmers Group in Kabale district. Regoverning Markets Innovative Practice Series. 
AMPAIRE, E. L., MACHETHE, C. L. \& BIRACHI, E. 2013. The role of rural producer organizations in enhancing market participation of smallholder farmers in Uganda: Enabling and disabling factors. Afri. J. Agric. Res., 8(11): 963-970.

BAAH, F. 2008. Harnessing farmer associations as channels for enhanced management of cocoa holdings in Ghana. Sci. Res. Essays, 3(9):395-400.

BEST, R., FERRIS, S. \& SCHIAVONE, A. 2005. Building linkages and enhancing trust between small-scale rural producers, buyers in growing markets and suppliers of critical inputs. In Beyond agriculture-making markets work for the poor. Proceedings of an international seminar (Vol. 28, pp. 19-50).

BOND, J. K., CARTER, C. A. \& SEXTON, R. J. 2009. A study in cooperative failure: Lessons from the Rice Growers Association of California. Journal of Cooperatives, 23: 71-86.

BOU. 2016. Bank of Uganda. Annual report 2015/2016.

CIDI. 2013. Community Integrated Development Initiatives (CIDI). Annual report 2012/2013.

DAVIS, K., NKONYA, E., KATO, E., MEKONNEN, D. A., ODENDO, M., MIIRO, R. \& NKUBA, J. 2010. Impact of farmer field schools on agricultural productivity and poverty in East Africa. IFPRI Discussion Paper 00992.

EGERU, A. \& MAJALIWA, M. G. J. 2016. Hostages of subsistence cultivation: Can they be bailed? RUFORUM Working Document Series (ISSN 1607-9345) No. 14 (1): 707-717.

FACTFISH. 2015. Uganda: Sorghum yield (hectogram per hectare). Available [ONLINE] at: $\mathrm{http} / / / \mathrm{www}$. factfish.com/statistic-country/uganda/sorghum,\%20yield [Accessed 10th November, 2015].

FISCHER, E. \& QAIM, M. 2012. Linking smallholders to markets: determinants and impacts of farmer collective action in Kenya. World Dev, 40(6): 1255-1268.

GIBSON, R. W., BYAMUKAMA, E., MPEMBE, I., KAYONGO, J. \& MWANGA, R. O. 2008. Working with farmer groups in Uganda to develop new sweet potato cultivars: decentralisation and building on traditional approaches. Euphytica, 159(1-2): 217-228.

HELLIN, J., LUNDY, M. \& MEIJER, M. 2009. Farmer organization, collective action and market access in Meso-America. Food Policy, 34(1): 16-22.

HOLlOWAY, G., NICHOLSON, C., DElGADO, C., STAAL, S. \& EHUI, S. 2000. Agroindustrialization through institutional innovation Transaction costs, cooperatives and milk-market development in the east-African highlands. Int. J. Food. Agric. Econ., 23(3):279-288.

KAGANZI, E., FERRIS, S., BARHAM, J., ABENAKYO, A., SANGINGA, P. \& NJUKI, J. 2009. Sustaining linkages to high value markets through collective action in Uganda. Food policy, 34(1): 23-30.

KWAPONG, N. A. \& KORUGYENDO, P. L. 2010. Revival of agricultural cooperatives in Uganda. IFPRI USSP Policy Note, (11).

LA FERRARA, E. 2002. Inequality and group participation: theory and evidence from rural Tanzania. J. Public Econ., 85(2): 235-273.

LOEVINSOHN, M. E., MUGARURA, J. \& NKUSI, A. 1994. Cooperation and innovation by farmer groups: Scale in the development of Rwandan valley farming systems. Agricultural Systems, 46(2): 141-155.

MACAULEY, H. \& RAMADJITA, T. 2015. Cereal crops: rice, maize, millet, sorghum and wheat. AbdouDiouf International, Dakar Senegal.

MAGINGXA, L. L. \& KAMARA, A. B. 2003. Institutional perspectives of enhancing smallholder market access in South Africa. In 41st Annual Conference of the Agricultural Economic Association of South Africa held in Pretoria. 
MBOWA, S., SHINYEKWA, I. \& MAYANJA LWANGA, M. 2012. Dairy sector reform and transformation in Uganda since the 1990s. Economic Policy Research Centre (EPRC) In Collaboration with Africa Growth Initiative (AGI), Brookings.

MULU-MUTUKU, M. W., ODERO-WANGA, D. A., ALI-OLUBANDWA, A. M., MALING'A, J. \& NYAKEYO, A. 2013. Commercialisation of traditional crops: Are Cassava production and utilisation promotion efforts bearing fruit in Kenya? Int. J. Dev. Sustain, 6(7): 48-58.

NARROD, C., ROY, D., OKELlO, J., AVENDAÑO, B., RICH, K. \& THORAT, A. 2009. Public-private partnerships and collective action in high value fruit and vegetable supply chains. Food Policy, 34(1): 8-15.

OLSON, M. 2009. The logic of collective action (Vol. 124). Harvard University Press.

ORTMANN, G. F. \& KING, R. P. 2007. Agricultural cooperatives I: History, theory and problems. Agrekon, 46(1): 18-46.

PENG, C. Y. J. \& SO, T. S. H. 2002. Logistic regression analysis and reporting: A primer. Understanding Statistics, 1(1): 31-70.

PERTEV, R. 2014. The Role of farmers and farmers' organizations. Cahiers Options Méditerranéennes, 2(4).

POOLE, N. \& DE FREECE, A. 2010. A review of existing organisational forms of smallholder farmers' associations and their contractual relationships with other market participants in the East and Southern African ACP region.

ROY, D. \& THORAT, A. 2008. Success in high value horticultural export markets for the small farmers: The case of Mahagrapes in India. World Dev, 36(10): 1874-1890.

RWELAMIRA, J. 2015. Strengthening farmers organizations and civil society organizations. Available [ONLINE] at: https://www.afdb.org/fileadmin/uploads/afdb/Documents/Events/DakAgri2015/Strengthe ning_Farmers_Organizations_and_Civil_Society_Organizations.pdf [Accessed 9 February, 2017].

SABATES-WHEELER, R. 2006. Safety in small numbers: local strategies for survival and growth in Romania and the Kyrgyz Republic.

SHIFERAW, B., OBARE, G. \& MURICHO, G. 2006. Rural Institutions and producer organizations in imperfect markets: experiences from producer marketing groups in semi-arid eastern Kenya. Socioeconomics and Policy Working Paper Series no. 23.

STOCKBRIDGE, M., DORWARD, A. \& KYDD, J. 2003. Farmer organizations for market access: A briefing paper. Wye Campus, Kent, England: Imperial College, London

TOLNO, E., KOBAYASHI, H., ICHIZEN, M., ESHAM, M. \& BALDE, B. S., 2015. Economic analysis of the role of farmer organizations in enhancing smallholder potato farmers' income in middle Guinea. J. Agri. Sci., 7(3): 123.

TOWO, E. 2004. The gender dimension of rural producer organisations in Tanzania. Norwegian Institute for Urban and Regional Research and Participating Institutions (NIBR)-Business Experience Exchange Programme (BEEP), Working Paper, 131.

UBOS. 2010. Uganda Bureau of Statistics: summary report on Uganda census of agriculture 2008/2009.

[ONLINE]

Available at:http://www.ubos.org/onlinefiles/uploads/ubos/pdf\%20documents/UCASummary.pdf [Accessed 25th April, 2015].

USAID. 2010. Market assessment and baseline survey of staple foods. Country reportUganda. [ONLINE] Available at: http://pdf.usaid.gov/pdf_docs/Pnadw642.pdf [Accessed 11th August, 2015].

WANG, Y. T. 1979. The roles of farmers' associations and agricultural development programmes in Taiwan. In 17. International Conference of Agricultural Economists, Banff (Canadá), 3-12. 
S. Afr. J. Agric. Ext.,

Vol. 45, No. 1, 2017: $118-130$

DOI: http://dx.doi.org/10.17159/2413-3221/2017/v45n1a444

WOLLNI, M. \& ZELLER, M. 2007. Do farmers benefit from participating in specialty markets and cooperatives? The case of coffee marketing in Costa Rical. J. Agric. Econ., 37(2-3): 243-248.
Ekepu, Tirivanhu

\& Nampala.

(Copyright) 